\title{
Social Media Marketing in Emerging Economies: A Mongolian Case Study
}

\author{
David R. Borker ${ }^{1}$ \\ ${ }^{1}$ Department of Economics, Finance and Management, Manhattanville, College, Purchase, USA \\ Correspondence: David R. Borker, Manhattanville, College, 2900 Purchase Street, Purchase, NY 10577, United \\ States. Tel: 1-203-918-9600. E-mail: david.borker@mville.edu
}

Received: December 9, $2013 \quad$ Accepted: January 17, $2014 \quad$ Online Published: March 24, 2014

doi:10.5539/ijms.v6n2p31 URL: http://dx.doi.org/10.5539/ijms.v6n2p31

\begin{abstract}
There exists substantial research on social media marketing (SMM) in the United States and other developed countries. Studies of SMM in emerging economies, such as the eleven Global Growth Generator (3G) economies, are rare. This study seeks to discover and characterize the use of social media marketing channels in the Republic of Mongolia, an emerging economy, transitioning from socialism and at the earliest stages of marketing development. The study is limited to twenty companies listed on the Mongolia stock exchange. These companies are categorized by whether they are involved in social media marketing based on direct or indirect presence on Facebook, YouTube, or Twitter with supporting quantitative data on activity levels. Also, specific content is examined descriptively in order to characterize the primarily functions of social media marketing in this special environment.
\end{abstract}

Keywords: social media marketing, emerging economies, $3 \mathrm{G}$ economies, Mongolia

\section{Introduction}

In the past five years, social media marketing has become the predominant mode of marketing on the Internet. Social media can be defined as a group of Internet-based applications that build on the ideological and technological foundations of Web 2.0, and allow the creation and exchange of user-generated content. (Kaplan Andreas M., 2010) Social media marketing refers to the process of gaining website traffic or attention through social media sites. These consumer online brand related activities (COBRAs) attract the attention of users who are motivated to share content within their social network. A company's marketing message spreads from user to user and is more likely to resonate, since it appears to come from a trusted third-party source.

Whereas there is a large body of popular and scholarly literature on SMM in the United States and other developed economies, information on SMM in emerging and developing economies is sparse. This paper observes and describes evidence of SMM activity in the Republic of Mongolia, the smallest but fastest growing economy in the Global Growth Generator group (3G), projected to be the fastest growing economies through 2050. (Buiter \& Rahbari, 2011) The paper examines evidence of SMM activity among a sample of twenty prominent Mongolian listed companies that comprise the MSE Top Twenty Index. The study provides a quantitative breakdown of SMM users and user activity levels, as well as, a qualitative description of content being offered. It focuses on the three most well-known global social media channels, i.e., Facebook, YouTube, and Twitter. This study presents an opportunity to observe and monitor the very early development of SMM in an emerging economy by local companies.

In the remainder of this paper, Section 2 reviews the existing literature on SMM and general media marketing in emerging economies and identifies important issues about this research area. Section 3 provides background country-specific information on Mongolia and its place among the $3 \mathrm{G}$ economies, including demographic data relevant to Mongolia's ability to effectively nurture SMM and general Internet marketing. Section 4 describes the design of the Mongolian SMM study, including sources and methods of data collection. Sections 5-7 present the results of the study, based on quantitative and qualitative analysis of the data collected. Section 8 discusses the results of the study and Section 9 provides conclusions and directions for further research on SMM in Mongolia and in other emerging economies. 


\section{Review of the Literature}

There is extensive literature on the development, theory and technologies of SMM in the United States, the U.K. and other developed countries. Reviewing this extensive work is not an objective of this paper. It suffices to acknowledge the academic and pragmatic work of numerous scholars and researchers (Berthon, Pitt, Plangger, \& Shapiro, 2012; Kaplan \& Haenlein, 2010; Fisher, 2009; Chana \& Guilleta, 2011; Trusov, Bucklin, \& Pauwels, 2008; Thackeray, Neiger, Hanson, \& McKenzie, 2008; Constantinides, 2008; Jansen, 2009; Piskorski, 2010; Subramani, 2003; Weber, 2009). This research has explored how the features of Internet social media work to produce often viral dissemination of information, as well as, information on the use and development of social media as a marketing tool by companies of all sizes. As with the Internet in general, SMM is a capability available to all commercial players from the smallest entrepreneurs to the largest multinationals.

On the topic of SMM as an internal phenomenon in emerging or developing economies, there is almost no literature available. Possible exceptions to this statement include a study that addresses the potential benefit to emerging economies of employing Internet based marketing in the area of eco-tourism through company websites and blogs (Sambhanthan \& Good, 2012). Also, some researchers have studied social media and microblog traffic relating to buying and selling activities and compare data for developed versus emerging markets (Gilfoil, 2012; Jobs, 2011; Jobs \& Gilfoil, 2011). These studies, however, do not examine SMM activity of actual companies and limit their observations of emerging economies to the BRIC group (Brazil, Russia, India, China) and NIC (Mexico, Malaysia) markets.

Outside of SMM and the Internet, some researchers have also addressed the general value of studying emerging markets as a means of advancing marketing science (Burgess \& Steenkamp, 2006). Even general studies of social media marketing in the developing world are highly limited and conducted primarily from the point of view of western economies and their multinationals seeking opportunities to gain footholds for their own products and services within developing countries. However, some researchers have stressed the importance of understanding psychological and cultural aspects of emerging and developing economies in developing marketing strategies. One study points out how consumption in United States and the general process of globalization both influence emerging markets (Dholakia \& Talukdar, 2004). Another stresses impediments to market penetration caused by traditional, anti-globalism attitudes in emerging countries (Witkowski, 2005). Others try to define cultural characteristics of the emerging market and the need to focus on issues of poverty in pursuing this market (N. Dawar \& Chattopadhyay, 2002; Kirchgeorg \& Winn, 2006).

This paper focuses on the status of SMM activity for local Mongolian companies, rather than considering the opportunities for foreign multinational companies to gain market share through SMM, which they appear to be doing. The research goal is to identify SMM users within the MSE Top Twenty companies and their relative levels of SMM activity for the three SMM channels studied, as well as, to characterize the nature of the content that is provided.

\section{Background: Mongolia and the 3G}

\subsection{The Republic of Mongolia}

Mongolia is historically a nomadic animal raising culture, although, today most of its population lives in cities. After centuries of military struggle in which Mongolia has dominated and been dominated by its neighbors Russia and China, the country fell under Soviet domination from 1924 until 1990. As elsewhere in the Soviet world, Mongolia has inherited a mixed legacy of relatively high literacy rates and educational levels, along with alcoholism and corruption (Finpro, 2012). Mongolia's scores on the Corruption Perception Index show it to be significantly less corrupt than post-Soviet Russiaand Kazakhstan, but more corrupt than the Republic of China (Transparency International, 2012). It is important to be aware of Mongolia's current transition from Socialist dictatorship to a democratic free market society, as this helps to explain the difficulties of adapting to Western marketing and open disclosure in general. We see this in the Top 20 companies investigated in this study. The only retail-diversified company in our sample is UID or State Department Store. Knowing its Communist origins, it is not surprising that this company does not prove to be a major SMM/ Internet marketer. Similar issues arise for many of the larger mining and other heavy industrial companies that were all state enterprises prior to 1990. Mongolia has high growth expectations based mostly on its rich natural mineral resources. Its major production is from construction and construction materials, mining, food and beverages, processing of animal products, and cashmere and natural fiber manufacturing (World Bank, 2013). 


\subsection{Mongolia and the Internet}

Worldwide, the social networks with the highest numbers of registered users in 2011 were Facebook with 680+ million, QQ, or Q-zone, with 480 million, and Twitter and Habbo with 200 million each. Mongolia, like its neighbor Kazakhstan and the other central Asian former Soviet republics, is most heavily Facebook oriented. This is in contrast to its two mega-neighbors to the north and south, Russia and China. In Russia, and the other former Slavic Soviet republics, the local social network Vkontakte (110 million users) dominates and in China most use QQ, a Chinese censor-controlled network.

Table 1. Internetand facebook penetration 2011-users of each as a percent of total population (Internet World Stats, 2012)

\begin{tabular}{llll}
\hline 3G Countries & $\begin{array}{l}\text { Internet User } \\
\text { Penetration \% }\end{array}$ & 3G Countries & $\begin{array}{l}\text { Facebook User } \\
\text { Penetration \% }\end{array}$ \\
\hline China & $38.4 \%$ & Philippines & $27.2 \%$ \\
Vietnam & $34.1 \%$ & Indonesia & $17.7 \%$ \\
Philippines & $33.0 \%$ & Mongolia & $\mathbf{1 4 . 6 \%}$ \\
Nigeria & $29.0 \%$ & Egypt & $11.4 \%$ \\
Egypt & $26.4 \%$ & Sri Lanka & $5.8 \%$ \\
Indonesia & $22.4 \%$ & Iraq & $4.3 \%$ \\
Sri Lanka & $11.8 \%$ & India & $3.8 \%$ \\
Mongolia & $\mathbf{1 1 . 3 \%}$ & Vietnam & $3.5 \%$ \\
India & $10.2 \%$ & Nigeria & $2.8 \%$ \\
Iraq & $4.3 \%$ & Bangladesh & $1.6 \%$ \\
Bangladesh & $3.5 \%$ & China & $0.0 \%$ \\
\hline
\end{tabular}

Focusing on emerging economies and, in particular, the eleven 3Gs, we can observe how Mongolia, the smallest $3 \mathrm{G}$ by population, compares with the others with regard to Internet and Facebook user penetration. Table 1 shows the ranking of the 3 Gs based on the number of Internet users and the number of Facebook users within the total population.

Despite Mongolia's relatively low rank for Internet penetration, it ranks third for Facebook penetration within the group. This is in contrast to China, which ranks highest for Internet penetration, but has very low Facebook penetration due to the domination of the state run site QQ. Recent reports of Mongolian Twitter activity during the 2012 Olympics and other reports suggest that Mongolia also has a strong Twitter user base. Of the pure social media networks, excluding content communities like YouTube, Mongolians do use Badoo, a dating-focused social discovery website, founded in 2006 that operates in 180 countries and is most active in Latin America, Spain, Italy and France. Badoo has branched out into job search in these countries, but appears to be used primarily for dating connections in Mongolia. Linked-In claims no significant user penetration in Mongolia. However, there is some evidence of its use by international business concerns in Mongolia, especially in connection with finding job candidates internationally. No other global social networks were found have a significant presence in Mongolia.Of the content community sites, Google's YouTube is the dominant site worldwide for uploading and downloading videos and isused extensively in Mongolia.

\section{Purpose and Design of Mongolian Study}

The Mongolian study focuses on the use of Facebook, YouTube, and Twitter as social media marketing tools by a sample of large Mongolian companies. The sample consists of the Top 20 list of MSE stocks on July 31, 2012. 
Table 2. Top 20 companies used as sample for study (Mongolian Stock Exchange, 2012)

\begin{tabular}{lllllll}
\hline & Company Name & MSE & Sector & $\begin{array}{l}\text { 2012NetSales } \\
\text { \$Mil }\end{array}$ & $\begin{array}{l}\text { 2012Tot. } \\
\text { Assets\$Mil }\end{array}$ & Company Website \\
\hline 1 & Bayangol ZB & BNG & Hotels \& Motels & 6.18 & 22.43 & www.bayangolhotel.mn \\
2 & Talkh Chikher & TCK & Food-Bev.-Bakery & 15.31 & 24.19 & www.talkh-chikher.mn \\
3 & APU & APU & Food-Bev.-Brewery & 203.10 & 123.43 & www.apu.mn \\
4 & Telecom & MCH & Telecommunication & 8.71 & 29.69 & www.mtcone.net \\
& Mongolia & & & & & \\
5 & Shariin gol & SHG & Mining Related & 10.20 & 29.88 & www.sharyngol.mn \\
6 & SILIKAT JSC & SIL & Manufacture & N/A & 6.57 & www.silikat.mn \\
7 & Gobi & GOV & Manufacture & 29.16 & 49.22 & www.gobi.mn \\
8 & Baganuur & BAN & Mining Related & 52.64 & 63.38 & www.baganuurmine.mn \\
9 & Mogoin gol & BDL & Mining Related & 0.85 & 1.99 & none \\
10 & Tavantolgoi & TTL & Mining Related & 154.64 & 48.89 & www.erdenestt.mn \\
11 & Shivee ovo & SHV & Mining Related & 19.24 & 63.37 & none \\
12 & Aduunchuluun & ADL & Mining Related & N/A & 2.83 & www.aduunchuluun.mn \\
13 & State Department & UID & Retail-Diversified & 0.69 & 8.38 & none \\
& Store & & & & & \\
14 & Berkh uul & BEU & Mining Related & 0.66 & 0.72 & www.berkhuul.mn \\
15 & Mongol shiltgeen & MSH & Hotels \& Motels & 0.67 & 4.07 & none \\
16 & GenkoTour & JTB & Travel Services & 2.05 & 6.52 & www.genco.mn \\
& Bureau & & & & & \\
17 & BDSec & BDS & Financial & 3.48 & 7.21 & www.bdsec.mn \\
18 & TuulSongino & MDR & Financial & 0.40 & 13.24 & www.mdr.mn \\
& Usnii Nuuts & & & & & \\
19 & Remikon & RMC & Electrical Power & 12.28 & 13.18 & www.remicon.mn \\
20 & Khukh gan & HGN & Mining Related & 0.31 & & \\
\hline
\end{tabular}

The Top 20 Index rankings are computed by the MSE using a specific formula that includes level of market capitalization and trade volume. See the MSE website for details on this calculation. The MSE website has an English language option. A complete list of the companies with their websites is provided in Table 2.

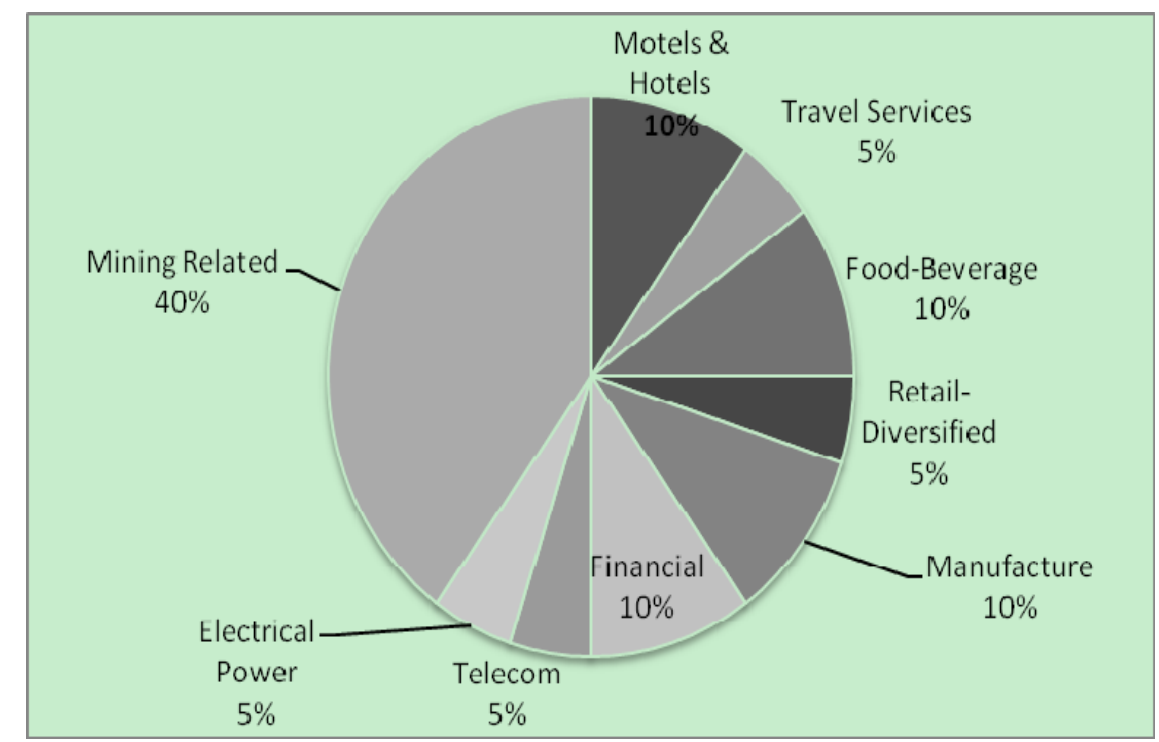

Figure 1. MSE top 20 companies by industry

Note. Sample Size 20 Companies (Mongolian Stock Exchange, 2012). 
The MSE Top Twenty Index consists of companies from a variety of industries. Figure 1 provides a breakdown of industry sectors. In the MSE Top 20, the Mining Related sector comprises the largest number of companies, eight in total. This is not surprising given that Mongolia's primary importance as a $3 \mathrm{G}$ economy is its wealth of natural mineral resources. Although Mongolia has a rich diversity of minerals, the majority of the mining companies in the MSE Top 20 are coal producers. These companies are natural investment targets for foreign companies and one would expect that much of their social media marketing would utilize English in addition to Mongolian. The Motels \& Hotels and Travel Services sectors represent $15 \%$ of the companies. They are strongly oriented toward foreign tourists and commercial visitors, as well as, Mongolian clients. Similarly, the financial sector focuses heavily on foreign investors. In addition, the manufacturing sector, which includes cashmere clothing products, popular in the west, and production of silk, brick and lime products, is of interest to foreign customers. Consequently, all of these sectors can be expected to use English in addition to Mongolianon their SMM sites. The Food-Beverage sector is comprised of a baked goods enterprise, producing primarily for the local market, and a brewery/distillery, producing for the local market, as well as, for the specialty export market.

\subsection{Data Collection}

During data collection, the Internet was searched for examples of SMM in each of the three social media studied. Examples were classified into two categories: direct utilization and indirect utilization. Direct utilization is defined as the use of a specific social medium through a direct account of the company, company officer or agent. Indirect utilization is defined as usage resulting from the use of an account not controlled by the company. Quantitative breakdowns of SMM users are provided in Figures 2 to 5 in total and by industry sector. Also, level of usage data for direct users is provided by company in Tables 3 to 5 . Content examples of both types of utilization are provided, for each type of social media tool examined, in Tables 6 to 8 . Evidence of the use of other social media, including blogs and other content media were also noted, but these are not included in the current analysis.

\section{Mongolian Study Results}

Overall, direct and indirect use of Twitter, Facebook and YouTube was found for many of the companies in the MSE Top 20.

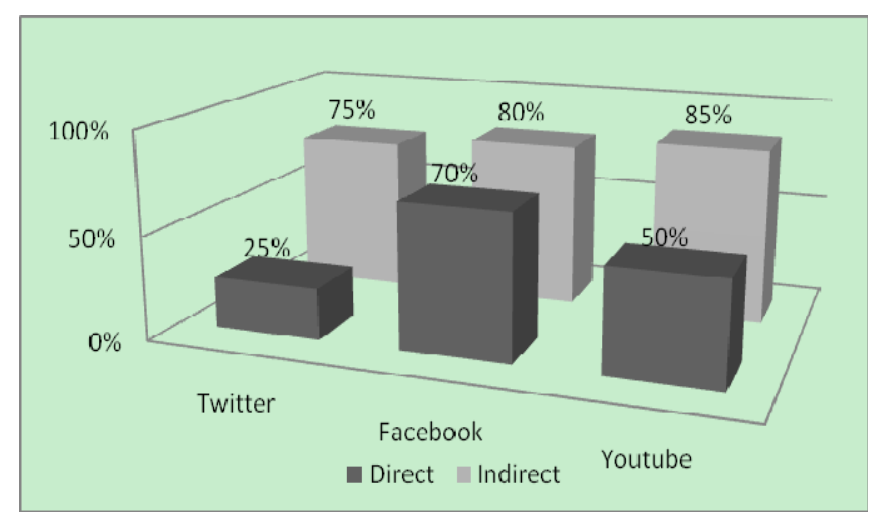

Figure 2. Percentage of MSE top 20 companies utilizing Twitter, Facebook and YouTube directly or indirectly

Note. sample size 20 companies.

Source: Internet.

Figures 2 summarizes the direct and indirect the utilization of the three media by percentage of companies.

Overall, for all three media, evidence of indirect utilization is significantly higher than direct utilization for the companies examined. The percentage of companies benefitting from indirect utilization ranges from 75 to $85 \%$, with YouTube at the high end and Twitter at the low end of this range. Evidence of direct utilization by companies indicates that Facebook is utilized by $70 \%$ of the companies, YouTube by $50 \%$ and Twitter by $25 \%$. Twitter shows the most significant difference between the level of direct utilization and indirect utilization, with YouTube showing a similar displacement. Whereas a majority of companies in the MSE Top 20 have 
established their own Facebook and YouTube direct presence, only a minority of companies choose the direct approach for Twitter.

\subsection{Breaking down Usage for Each SMM Platform by Industry Sectors}

It is necessary to break down the data closer to the company level to determine which types of companies choose direct utilization for Twitter, Facebook and YouTube, respectively. Such a breakdown is provided in Figures 4, 5 and 6 below, where evidence of the utilization of each of the social media is broken down by specific industry sectors represented in the MSE Top 20.

\subsection{Twitter Findings}

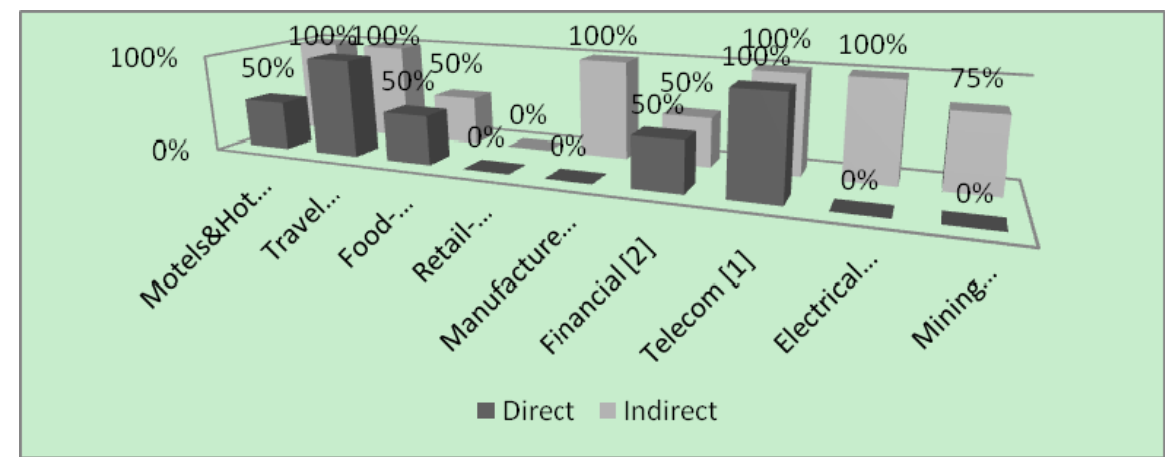

Figure 3. Percentage of MSE top 20 companies by industry using Twitter directly or indirectly

Note. sample size 20 companies.

Source: Internet.

Direct use of Twitter by a company for its own marketing purposes is evidenced in Travel Services, Food-Beverages, Financial, Telecom, and in one of the eight Mining Related companies (see Figure 3). In the case of Travel Service and Financial companies, in addition to advertising themselves, they prove to be major indirect Twitter marketers for other companies in the MSE Top 20. The Travel Services company focuses on the Motels \& Hotels sector, highlighting special facilities events occurring at the latter. One of the companies in the Financial sector shares information about MSE 20 stocks that it trades. It is responsible for much of the indirect Twitter information on the Mining Related and Electrical Power groups. Other trade organizations also tweet indirectly about many of the companies, including the cashmere products manufacturer. The presence of both direct and indirect tweets relating to the one large Telecom company appears to reflect the role of this company as a service provider facilitating Twitter activity. It should be noted that one company from the Retail-Diversified sector showed no evidence of direct use of Twitter. All use of this medium is carried out indirectly by individuals and, perhaps, by small retailers at the individual shop or booth level. The former State Department Store might be expected to be less marketing oriented or more conservative in its marketing methods, leaving SMM activities to smaller independent venues within the territory of the giant department store.

Table 3. Individual Twitter statistics for direct Twitter users (Twitter)

\begin{tabular}{llll}
\hline Company & \#Tweets & \#Following & \#Followers \\
\hline Bayangol & 17 & 6 & 16 \\
Talkh Chikher & 2 & 18 & 12 \\
Telecom Mongolia & 61 & 1995 & 838 \\
Genko Tour Bureau & 111 & 115 & 41 \\
BDSec & 2897 & 71 & 919 \\
\hline
\end{tabular}

The Twitter data indicate a possible positive correlation between number of followers and companies with the characteristic of being an individual service provider. If the number of Twitter Followers by company all twenty companies is regressed against the presence or absence of the service characteristic, the result is a 
correlation of .60 and an R-square of .36. Since the P-value in the ANOVA is .005, this relationship may hold for a larger population than our sample.

\subsection{Facebook Findings}

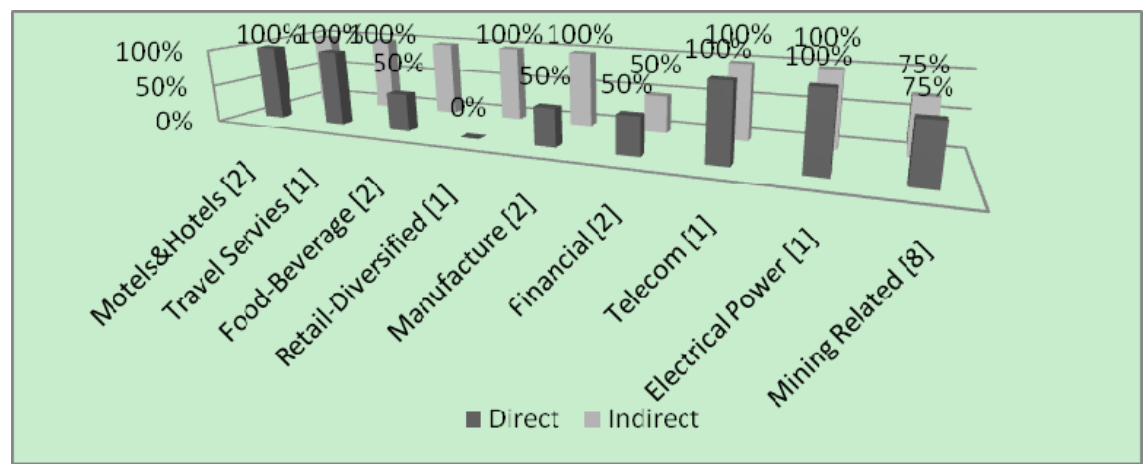

Figure 4. Percentage of companies by industry using Facebook directly or indirectly

Note. sample size 20 companies.

Source: Internet.

Facebook has the broadest evidence of direct utilization with every one of the industry sectors evidencing some use (see Figure 4). Furthermore, all companies in the Motels \& Hotels and Travel Services sectors have Facebook accounts. This is also the case for the Telecom sector. Three quarters of the eight companies in the Mining Related Sector and one of the two companies in the Food and Beverage and Financial sectors had direct Facebook presence. Although Facebook is the most likely candidate for direct utilization of the three social; media under study, a full $30 \%$ of the individual companies appear not to utilize their own Facebook account. One might well wonder if there are no other Internet options, such as company websites and blogs where some of these companies have a more direct Internet presence.

Table 4. Individual Facebook statistics for direct Facebook users (Facebook)

\begin{tabular}{llllllll}
\hline Company & \#Likes (Fans) & $\begin{array}{l}\text { Highest } \\
\text { /week }\end{array}$ & $\begin{array}{l}\text { Lowest/ } \\
\text { week }\end{array}$ & $\begin{array}{l}\text { \#Talking } \\
\text { About }\end{array}$ & $\begin{array}{l}\text { Highest } \\
\text { /week }\end{array}$ & $\begin{array}{l}\text { Lowest } \\
\text { /week }\end{array}$ & $\begin{array}{l}\text { Most Pop } \\
\text { Age }\end{array}$ \\
\hline Bayangol ZB & 950 & 33 & 9 & 164 & 186 & 35 & $18-24$ \\
Talkh Chikher & 3690 & 8 & 0 & 33 & 78 & 5 & $18-24$ \\
Telecom Mongolia & 695 & 15 & 1 & 90 & 100 & 15 & $18-34$ \\
Shariin gol & 146 & 10 & 0 & 7 & 11 & 0 & $18-24$ \\
Gobi & 60435 & 1434 & 76 & 1810 & 2912 & 211 & $18-24$ \\
Tavantolgoi & 49 & 12 & 0 & 2 & 13 & 0 & $25-34$ \\
Shivee ovo & 154 & 6 & 0 & 5 & 5 & 1 & $18-24$ \\
Aduunchuluun & 25 & N/A & N/A & 1 & N/A & N/A & N/A \\
Berkh uul & 53 & 1 & 0 & 1 & 1 & 0 & $25-34$ \\
Mongol shiltgeen & 579 & N/A & N/A & N/A & N/A & N/A & N/A \\
Genko Tour Bureau & 8353 & 144 & 15 & 173 & 680 & 52 & $18-24$ \\
BDSec & 1608 & 14 & 0 & 64 & 127 & 40 & $18-24$ \\
Remikon & 155 & 3 & 2 & 1 & 6 & 2 & $25-34$ \\
Khukh gan & 548 & 11 & 1 & 6 & 11 & 3 & $18-24$ \\
Total (Avg./Median) & $5531 / 89.5$ & & & & & & \\
Mining (Avg./Median) & $163 / 99.5$ & & & & & & \\
Non-Mining (Avg./Median) & $9558 / 1279$ & & & & & & \\
\hline
\end{tabular}

Gobi, a major retailer of cashmere fashion goods, has by far the highest number of fans $(60,435)$, of which $90.7 \%$ are in Mongolia. Of the three runner ups, two offer individual services and one is a major baker/retailer. The contrast between averages and medians for the mining versus non-mining companies appears to reflect the relatively lower importance of Facebook for mining companies that are not retail customer oriented and sell 
most of the production abroad. Using multivariate regression analysis, regressing total fans (or likes) against the independent variables Net Sales in \$millions, Total Assets in \$ millions, and the company characteristic of mining yield the strongest correlation at .52 with an R-square of .27. Sales have a positive coefficient and Assets and the mining characteristic had negative coefficients. However, the relationship among variables cannot be generalized beyond the sample, since the regression and none of the variable coefficients have acceptable P-values.

In contrast to direct utilization, indirect presence on Facebook is evidenced in all the industry sectors and $80 \%$ of the individual companies. Only three Mining Related companies and one Financial company did not evidence indirect Facebook utilization. Given the high incidence of indirect Facebook presence and the relative lack of control that each company has over this phenomenon, it would not be surprising, with more extensive examination, to find that there is some indirect Facebook presence for all companies.

\subsection{YouTube Findings}

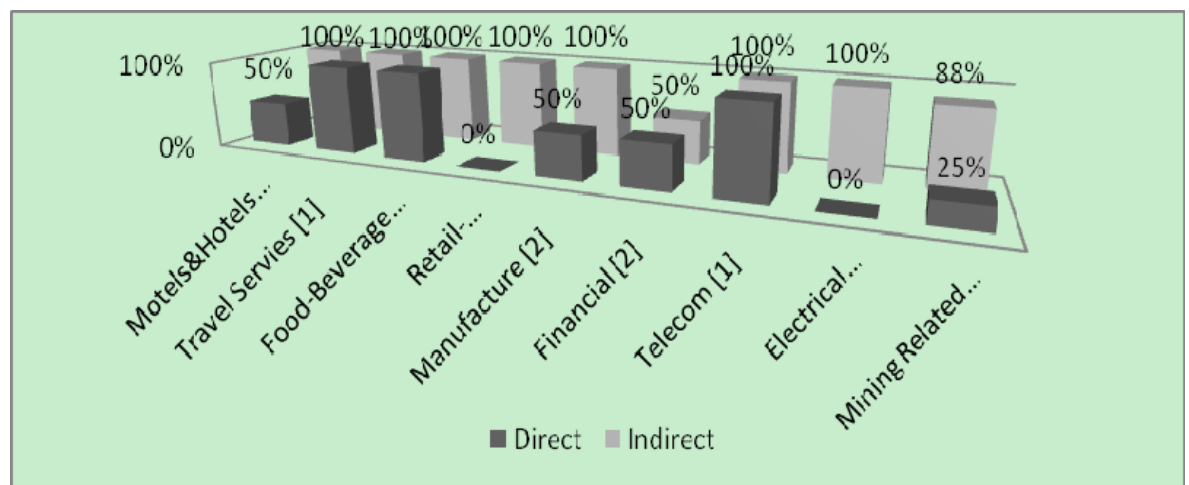

Figure 5. Percentage of MSE companies by industry using YouTube directly or indirectly

Note. sample size 20 companies.

Source: Internet.

As is the case with Facebook direct utilization, all companies in the Motels \& Hotels, Travel Services, the Food-Beverage, and Telecom sectors showed evidence of direct YouTube utilization (see Figure 5). Although videos can also be uploaded to Facebook, all the companies and indirect users were found to upload their videos to YouTube, and, in a few cases, another dedicated video content provider site, similar to YouTube. Videos are, of course, a very special tool, since, among their various capabilities, they can function as an extension or substitute for television commercials. Furthermore, YouTube videos can be significantly longer than normal TV commercials without imposing on the viewer. For these reasons, it is not surprising that direct utilization of YouTube is most evident among companies providing personal consumption and services for individual consumers, e.g., cakes and tasty snacks, alcoholic beverages, travel and cell phone services.

Table 5. Individual YouTube data by direct user (YouTube)

\begin{tabular}{llll}
\hline Company & \# Videos & Largest \# Views & Total \#Views \\
\hline Talkh Chikher & 7 & 373 & 4199 \\
APU & 2 & 5437 & 9668 \\
Telecom Mongolia & 19 & 168 & 1558 \\
Gobi & 10 & 3416 & 8298 \\
Tavantolgoi & 6 & 110 & 390 \\
Shivee ovo & 2 & 217 & 404 \\
Mongol shiltgeen & 1 & 1126 & 1126 \\
Genko Tour Bureau & 12 & 11820 & 13208 \\
BDSec & 11 & 17351 & 18061 \\
Remikon & 1 & 53 & 53 \\
Total Average/Median & $7 / 13$ & $4007 / 1499$ & $5697 / 5757$ \\
Ind. Consumer Sales-service Average/Median & $9 / 10$ & $5670 / 3416$ & $8017 / 8298$ \\
Other Average/ Median & $3 / 2$ & $127 / 110$ & $282 / 390$ \\
\hline
\end{tabular}


The two direct YouTube users with the highest views totals, BDSec and Genko Tour Bureau, are both providers of individual services. Among YouTube users, individual service and manufacture/retailers have average scores for all categories materially higher than for other types of companies.

Evidence of indirect utilization of YouTube, at $85 \%$, is higher than even for Facebook, at $80 \%$. In $80 \%$ of the industry sectors, $100 \%$ of the companies evidence indirect YouTube utilization. In the remaining sectors, $88 \%$ of the Mining Related and $100 \%$ of the Manufacturing companies also show indirect utilization. There is a significant positive correlation between Number of Total Views and the company characteristic Consumer Sales-service. A simple regression of the one against the other for all companies in the sample produces a positive correlation of .67 and .44 with a P-value of .001 . This would indicate that this relationship could be generalized beyond the sample.

\subsection{Reflections on Quantitative Sample Data}

The data results above provide answers as to which of the MSE Top 20 companies directly and indirectly utilize each of the three SMM channels selected for analysis and the supplementary quantitative usage data gives some idea on the impact and level of activity of the direct users, as well as insights into the industry sectors that are more or less active. This quantitative information does not, however, provide a qualitative look at the kind of content that these companies are creating. This requires a content oriented analysis of the characteristics of SMM utilization with specific examples from companies in the sample.

\section{Analysis of Utilization Characteristics with Specific Examples from Each Social Medium}

Characteristics of direct and indirect utilization of Twitter, Facebook and YouTube are discussed in the three subsections that follow. This is the level of analysis at which it becomes evident how the three SMM platforms are used by, or on behalf of, Mongolian companies. Individual characteristics and Internet examples of each characteristic are provided for each of the three SMM platforms.

\subsection{Characteristics of Twitter Utilization}

Table 6. Characteristics of MSE top 20 Twitter utilization (source: internet)

\begin{tabular}{|c|c|c|}
\hline \multicolumn{3}{|c|}{ TWITTER DIRECT } \\
\hline \multicolumn{2}{|c|}{ Characteristics } & \multirow{2}{*}{$\begin{array}{l}\text { Example } \\
\text { Talkh Chikher }\end{array}$} \\
\hline (a) & Short Company description & \\
\hline & & $\underline{\text { https://twitter.com/talkhchikherjsc }}$ \\
\hline (b) & $\begin{array}{l}\text { Company picture sets or invitation to } \\
\text { photo-album on Facebook }\end{array}$ & $\begin{array}{l}\text { BDSec } \\
\text { https://twitter.com/BDSecJSC/status/202671029510877185 }\end{array}$ \\
\hline \multicolumn{3}{|c|}{ TWITTER INDIRECT } \\
\hline \multicolumn{2}{|c|}{ Characteristics } & Example \\
\hline (a) & Prices, Specials, deals, discounts & $\begin{array}{l}\text { Bayangol Hotel } \\
\text { https://twitter.com/travellr/statuses/158020282353852416 }\end{array}$ \\
\hline (b) & $\begin{array}{l}\text { Company's stock performance and } \\
\text { financial events }\end{array}$ & $\begin{array}{l}\text { APU } \\
\underline{\text { https://twitter.com/Brauknecht/status/53763018055614464 }}\end{array}$ \\
\hline (c) & $\begin{array}{l}\text { Industry news on official twitter page; } \\
\text { news about companies }\end{array}$ & $\begin{array}{l}\text { Tavan Tolgoi } \\
\text { https://twitter.com/mongolianews/statuses/114234232955600896 }\end{array}$ \\
\hline (d) & Company as venue for events & $\begin{array}{l}\text { Bayangol Hotel } \\
\text { https://twitter.com/MMJhugjil }\end{array}$ \\
\hline
\end{tabular}

Specific characteristics of both direct and indirect Twitter utilization are identified along with actual examples of each from the Internet in Table 2.

The two primary characteristics of direct Twitter utilization are indicated in Twitter Direct (a) and (b) in Table 6 above. Short descriptions are relatively simple and grab attention, e.g., "Talkh Chikher is the leading 
manufacturer in the food industry in Mongolia." In addition, invitations to the company Facebook page with links to the company website or blog are often included.

The primary characteristics of indirect Twitter utilization are provided in Twitter Indirect (a) through (d) in Table 6 above. The most frequent conveyers of the above information are financial service companies, industry organizations and travel services companies. Since much of this information is intended for foreign investors, tourists and expats in the country, many of these tweets are in English or a mix of English and Mongolian. Distinguishing between direct and indirect Twitter utilization and, for that matter, the other two media, is the fact that some of the indirect references to a company are made by another company on the MSE Top 20. For example, the Financial sector company BDSec makes many stock market and important news event references to the Mining Related and other companies it is tracking for investors. In such tweets, BDSec could be said to be indirectly marketing a mining company, and, at the same time, directly marketing itself, using links to its own blogs and website.

\subsection{Characteristics of Facebook Utilization}

Table 7. Characteristics of MSE top 20 Facebook utilization (source: the internet)

\begin{tabular}{|c|c|c|}
\hline \multicolumn{3}{|c|}{ FACEBOOK DIRECT } \\
\hline \multicolumn{2}{|c|}{ Characteristics } & Example \\
\hline (a) & Invitation to visit company website & $\begin{array}{l}\text { Bayangol Hotel } \\
\text { https://www.facebook.com/pages/Bayangol-Hotel/117344788326642?sk=info }\end{array}$ \\
\hline (b) & Company description or resume & $\begin{array}{l}\text { BDSec } \\
\text { https://www.facebook.com/BDSecJSC/info }\end{array}$ \\
\hline (c) & $\begin{array}{l}\text { Promotion of special company customer } \\
\text { venues }\end{array}$ & $\begin{array}{l}\text { Bayangol Hotel } \\
\text { https://www.facebook.com/pages/Wine-House-Restaurant-Bayangol-Hotel/23446 } \\
\underline{6963264002}\end{array}$ \\
\hline (d) & Show picture album/ company photos & $\begin{array}{l}\text { Berkh Uul } \\
\text { https://www.facebook.com/berkhuul/photos_stream }\end{array}$ \\
\hline (e) & Sign up with Facebook to talk with us & $\begin{array}{l}\text { Talkh Chikher } \\
\text { https://www.facebook.com/TalkhChikher }\end{array}$ \\
\hline (f) & $\begin{array}{l}\text { Short service company messages to } \\
\text { customers }\end{array}$ & $\begin{array}{l}\text { Telekom Mongolia } \\
\text { https://www.facebook.com/TelecomMongoliaCompany }\end{array}$ \\
\hline (g) & Company map, directions, hours & $\begin{array}{l}\text { Bayangol Hotel } \\
\text { https://www.facebook.com/pages/Bayangol-Hotel/117344788326642?sk=info }\end{array}$ \\
\hline (h) & Prices, specials, deals, discounts, schedules & $\begin{array}{l}\text { Genco Tour Bureau } \\
\text { https://www.facebook.com/gencotourbureau/timeline }\end{array}$ \\
\hline \multicolumn{3}{|c|}{ FACEBOOK INDIRECT } \\
\hline & cteristics & Example \\
\hline (a) & $\begin{array}{l}\text { Reference to company location as a } \\
\text { landmark for giving directions }\end{array}$ & $\begin{array}{l}\text { Bayangol Hotel } \\
\text { Genco Tour Bureau - Timeline } \mid \text { Facebook }\end{array}$ \\
\hline (b) & Cited by another company & $\begin{array}{l}\text { Bayangol Hotel } \\
\text { https://www.facebook.com/BDSecJSC }\end{array}$ \\
\hline (c) & $\begin{array}{l}\text { Multiple updates on Mongolian business, } \\
\text { company events }\end{array}$ & $\begin{array}{l}\text { Tavantolgoi (Erdenes) } \\
\text { https://www.facebook.com/pages/THE-BUSINESS-COUNCIL-OF-MONGOLIA/ } \\
\text { 129826330435540YouTubeGanhuyag D } 20111028\end{array}$ \\
\hline (d) & $\begin{array}{l}\text { Advertise products sold at company } \\
\text { facilities }\end{array}$ & $\begin{array}{l}\text { State Department Store } \\
\text { https://www.facebook.com/GSCashmere/posts/310838428929192?comment id }=4 \\
\text { 606567\&offset }=0 \& \text { total_comments }=2\end{array}$ \\
\hline
\end{tabular}

Specific characteristics of both direct and indirect Facebook utilization are identified along with actual examples of each from the Internet in Table 7.

Characteristics of direct Facebook utilization are presented in Facebook Direct (a) through (i). Direct Facebook utilization is in its early stages and functions often to attract potential customers, through links, to company website and blogs. 
Characteristics of indirect Facebook utilization by companies are provided in Facebook Indirect (a) through (e). Indirect Facebook presence is facilitated by service companies and special industry organizations that are more sophisticated in their use of social media. Efforts are made to provide a regular flow of special interest news to target audiences. The travel service, financial service and trade companies recognize that both Facebook and Twitter are important first lines of contact that can only be maintained by providing new information of interest to tourists and investors.

\subsection{Characteristics of YouTube Utilization}

Table 8. Characteristics of MSE top 20 YouTube utilization (source: internet)

\begin{tabular}{|c|c|c|}
\hline \multicolumn{3}{|c|}{ YOUTUBE DIRECT } \\
\hline \multicolumn{2}{|c|}{ Characteristics } & Example \\
\hline (a) & $\begin{array}{l}\text { Product from raw materials to end } \\
\text { product/ consumer }\end{array}$ & $\begin{array}{l}\text { Talkh Chikher } \\
\text { http://www.YouTube.com/watch?v=IAiGHPyD9Yk }\end{array}$ \\
\hline (b) & $\begin{array}{l}\text { Series of attractive product samples } \\
\text { Commercial type }\end{array}$ & $\begin{array}{l}\text { Talkh Chikher } \\
\text { http://www.YouTube.com/watch?v=NOrhNnYGkog }\end{array}$ \\
\hline (c) & Quickie of one food product & $\begin{array}{l}\text { Talkh Chikher } \\
\text { http://www.YouTube.com/watch?v=HvLoHUGAj4s }\end{array}$ \\
\hline (d) & $\begin{array}{l}\text { Healthy product, natural products, use of } \\
\text { toddlers and childrenin scene }\end{array}$ & $\begin{array}{l}\text { Talkh Chikher } \\
\text { http://www.YouTube.com/watch?v=MC5VWMEgcj8 }\end{array}$ \\
\hline (e) & Local traditions - traditional product & $\begin{array}{l}\text { Talkh Chikher } \\
\text { http://www.YouTube.com/watch?v=CfZFbWUWesE }\end{array}$ \\
\hline (f) & $\begin{array}{l}\text { Traditional Mongol ceremonies at facility } \\
\text { or company activity }\end{array}$ & $\begin{array}{l}\text { Genco Tours } \\
\text { http://www.YouTube.com/watch?v=ew } 95 \mathrm{YHx} 7 \mathrm{zo} 8\end{array}$ \\
\hline (g) & $\begin{array}{l}\text { Rich western life style product } \\
\text { commercial (brand) }\end{array}$ & $\begin{array}{l}\text { APU } \\
\text { http://www.YouTube.com/watch?v=BwgMR3JctpQ }\end{array}$ \\
\hline (h) & Life style -Young people partying, sports & $\begin{array}{l}\text { APU } \\
\text { http://www.YouTube.com/watch?v=rvWEUnEJH3U }\end{array}$ \\
\hline \multicolumn{3}{|c|}{ YOUTUBE INDIRECT } \\
\hline \multicolumn{2}{|c|}{ Characteristics } & Example \\
\hline (a) & "Hotel room with a view" & $\begin{array}{l}\text { Bayangol Hotel } \\
\text { http://www.YouTube.com/watch?v=WpwmTbGoYa4 }\end{array}$ \\
\hline (b) & $\begin{array}{l}\text { Intercompany private sporting match/ } \\
\text { sport festival }\end{array}$ & $\begin{array}{l}\text { Baganuur } \\
\text { http://www.YouTube.com/watch?v=UEtI8aPTvro }\end{array}$ \\
\hline (c) & $\begin{array}{l}\text { Videos of CEO speaking, } \\
\text { attending industry meetings, sporting } \\
\text { events }\end{array}$ & $\begin{array}{l}\text { Sharyn Gol } \\
\text { http://www.YouTube.com/watch?v=LXkHz337y2s }\end{array}$ \\
\hline (d) & $\begin{array}{l}\text { Cooperation with USAID and Japanese } \\
\text { equipment company }\end{array}$ & $\begin{array}{l}\text { Baganuur } \\
\text { http://www.YouTube.com/watch?v=VVS5qHAI2qQ }\end{array}$ \\
\hline (e) & $\begin{array}{l}\text { Information critical of company - } \\
\text { Damaging the environment }\end{array}$ & $\begin{array}{l}\text { Tavantolgoi } \\
\text { http://www.YouTube.com/watch?v=p0ER4RAJ4P8 }\end{array}$ \\
\hline
\end{tabular}

Specific characteristics of both direct and indirect YouTube utilization are identified along with actual examples of each from the Internet in Table 8.

Characteristics of direct YouTube utilization by companies are indicated inYouTube Direct (a) through (h). Many of these direct examples function in much the same way as television commercials that promote brands and specific products to consumers. This is generally the case for the baked goods and snack producer /distributer Talkh Chikher, and the beverage company APU. Mongolian is the primary language used, although some of APU export label beers and liquors use some English to address the global consumer market.

Characteristics of indirect YouTube utilization by companies are provided in YouTube Indirect (a) through (e). The function of these indirect uses is not as obvious as for the direct cases. There are numerous videos of mining company CEOs at national sporting events, and speeches being given in what appear to be government settings. They do not appear to be uploaded by the company or a major industrial organization, but serve to present a positive image of the company leader. The inter/intra-company sporting matches are indoor basketball games without any significant audience. They may be purely intended for employee entertainment, so this use 
of YouTube can be seen as contributing to organizational harmony and cohesion. Since the games are available to anyone on the web, they can also be viewed as an indirect example of creating a good team image of the company for the consumer or the investing public.

Indirect utilization of YouTube is, by definition, not under the direct control of the company being spotlighted. Thus, it is not always the case that indirect use of YouTube is for the purpose of promoting companies and their industries to investors and consumers. The medium can also be a powerful tool for conveying negative views and facts about the companies. The best example of this is in the Mining Related sector. Financial services companies and pro-industry organizations provide typically positive public relations about the economic growth and success of these companies that are associated with Mongolia's status as a $3 \mathrm{G}$ economy. At the same time, many environmental groups made up of people from the agrarian sector, are concerned about the abuse of the environment caused by reckless mining operations that threaten the water tables of many regions and degrade the land. Mongolia's rural population still lives off its animals,as it has for millennia. Animals are used both for food and income. This way of life is threatened by water pollution and land degradation caused by careless leaching techniques in mining that poison the environment with dangerous chemical reagents. Indirect use of YouTube videos produced by local rural people and activist environmental groups expose examples of the destruction of natural environments by the mining and industrial concerns.

\section{Focusing in on Direct Facebook Utilizationby the MSE Top 20 Companies}

Seventy percent of companies have an official Facebook account. It appears that direct use of Facebook has become the most important part of many MSE Top 20 companies' Internet marketing strategies.

Table 9. Direct facebook accounts of MSE top 20 by company

\begin{tabular}{llll}
\hline Top 20 Rank & Company Name & $\begin{array}{l}\text { MSE } \\
\text { Ticker }\end{array}$ & $\begin{array}{l}\text { Direct } \\
\text { Facebook Account }\end{array}$ \\
\hline 1 & Bayangol ZB & BNG & $\bullet$ \\
2 & Talkh Chikher & TCK & $\bullet$ \\
3 & APU & APU & None (Note 1) \\
4 & Telecom Mongolia & MCH & $\bullet$ \\
5 & Shariin gol & SHG & $\bullet$ \\
6 & Silikat JSC & SIL & none \\
7 & Gobi & GOV & $\bullet$ \\
8 & Baganuur & BAN & none \\
9 & Mogoin gol & BDL & none \\
10 & Tavantolgoi & TTL & $\bullet$ \\
11 & Shivee ovo & SHV & $\bullet$ \\
12 & Aduunchuluun & ADL & $\circ$ \\
13 & State Department Store & UID & none \\
14 & Berkh uul & BEU & $\bullet$ \\
15 & Mongol shiltgeen & MSH & $\bullet$ \\
16 & Genko Tour Bureau & JTB & $\bullet$ \\
17 & BDSec & BDS & $\bullet$ \\
18 & Tuul Songino Usnii Nuuts & MDR & none \\
19 & Remikon & RMC & $\bullet$ \\
20 & Khukh Gan & HGN & $\bullet$ \\
\hline
\end{tabular}

Table 9 characterizes direct Facebook usage for each company. The circle symbols "•" and "०" both indicate that the company has a company Facebook account. An empty circle indicates that direct Facebook presence is minimal, e.g., just a name on a site under construction, or a simple location map, with no other content.

Facebook is overall the most common form of direct company presence in SMM. These data permit the comparison of the use of a company Facebook page with the existence of a company website. For company website information, see Table 2.As noted earlier, $70 \%$ of the companies examined have a registered company Facebook page, while $80 \%$ have a dedicated company website. Furthermore, $60 \%$ of the companies have both a company Facebook page and a company website, while $40 \%$ do not. Of the latter group, only $5 \%$ had neither a Facebook page nor a company website. This means that $35 \%$ of the companies have only a Facebook page or a 
Company website. This $35 \%$ breaks down as follows. Companies that have a Company website but no Company Facebook page make up 20\% of the total companies while companies with a company Facebook page but no website make up $15 \%$ of the companies. Implications of this information are considered in the discussion section of the paper.

\section{Discussion}

What do the study results tell us about usage and SMM strategies of Mongolia's Top 20 companies? First, all the Mongolian companies, with only two exceptions (Mogoin Gol and the State Department Store), seek a direct Internet presence through either a dedicated company website or a company Facebook page. The majority of companies $(\mathrm{N}=12)$ have both an established company website and a Facebook page and frequently use Facebook as a means to draw Facebook users' attention to the company website, where more information is provided about the company. The remaining companies show two different tendencies. Some companies rely on their company websites as their primary direct Internet presence, but, as yet, have not chosen to expand to Facebook (APU, SILIKAT, Baganuur and Tuul Songino Usnii Nuuts). Other companies that have not yet created a company website appear to have opted for a company Facebook account as a quick and less complicated way to establish direct presence on the Internet (Mongol shiltgeen and Shivee ovo).

Aduunchuluun is cited in Table 9 as having only a minimal Facebook presence. This means that its Facebook site has only been started and provides little more than the company name and, perhaps a location map. Two other companies (Mogoin gol and the State Department Store) have neither a company website nor a Facebook site and, based on this study, have no direct presence on the Internet. The State Department Store is a legacy of the long Soviet era in Mongolia's history, and is slowly adapting to western marketing concepts. It benefits primarily from indirect SMM presence on Facebook and YouTube. Much of this presence is the result of personal accounts of tourists and locals, who view the store as a curious historical landmark, and also of entrepreneurial shops operating inside the store that want to identify their location.

In some cases, Facebook is not the first choice for SMM presence. Some companies have a stronger direct presence on YouTube as compared to Facebook or Twitter, including Mongol Shiltgeen (a hotel chain) and APU and Talkh Chikher in the food and beverage sector. Of these companies, Apu and Mongol Shilgeen have no direct Facebook presence at all.

Twitter has the lowest direct usage among the Mongolian Top 20. Direct tweets are used primarily by companies providing financial and other news about themselves or their clients. This includes stock markets and brokerages, industry organizations and travel agencies. In the Top 20, they include BD Securities and Genko Tours. Also, companies like Talkh Chikher, which has a balanced direct utilization of all three SMM platforms, use Twitter as a means for disseminating news flashes about the company and products that take advantage of the immediacy and spontaneity of this platform.

In the case of Twitter and YouTube, quantitative data on total "likes" and "views" in direct utilization provided statistically significant positive correlations with specific company characteristics. Higher direct Twitter Follower volume is most likely for individual service provider companies like financial brokers, while higher direct YouTube volume is most likely for consumer sales or service companies like travel agents, brokers, hotels, bakeries and breweries. Facebook "fan" data also showed some level of correlation with several independent variables, using multivariate linear regression, but these results were not statistically significant based on P-values.

Analysis of the indirect utilization of the three social media channels examined revealed both the advantages and disadvantages of this type of content dissemination. Individuals and outside organizations having a positive or complementary relationship with the company facilitate the wider and more rapid dissemination of beneficial content. On the other hand, individuals or organizations having a critical attitude toward a company can produce undesirable content from that company's perspective that can become widely disseminated, as well. In Mongolia, Youtube has been a particularly effective vehicle for the latter type of content. Mongolia's mining companies are particularly sensitive and vulnerable to videos showing the negative impact of these enterprises on the ecology through air and water pollution and the loss of flora and fauna.

\section{Conclusion}

This study found initial evidence of the direct and indirect utilization of three SMM media sites by large Mongolian companies. Indirect and direct usage of Twitter, Facebook and YouTubewas observed and characterized for a limited number of the large Mongolian listed stock companies comprising the MSE Top 20 companies. The data indicate diverse levels of development with the strongest direct usage in the food/beverage 
and certain service companies, mostly in the hotel/travel and financial sectors. Both direct and indirect use of YouTube was generally an extension of television commercials, but also permitted longer pieces beyond normal duration limits. Indirect usage of SMM was generally greater than direct usage and was facilitated by various private and government service organizations and individuals.

Some limitations to this study should be noted. Twenty of the largest stock companies were investigated. Small and medium sized companies were outside the scope of the study. This, unfortunately, eliminated most entrepreneurial companies. The absence of information on smaller and non-stock companies excludes commercial sectors that have historically shown extensive use of SMM in the developed western markets. Since the scope of the study was data from Facebook, Twitter and YouTube, three major global social media platforms, only limited data was available for other global, regional and country-specific sites.

Opportunities for future research include:

- Investigation of medium and small stock and non-stock companies, including non-stock companies with emphasis on local entrepreneurship,

- Investigation of SMM activities in other global, regional and country-specific sites,

- Periodic follow up studies of SMM in Mongolia over time,

- Studies of the influence of cultural connections with Mongolia's neighbors and regional affiliates,i.e., Russia, China, Japan and Korea,

- Studies of SMM in other 3G markets in the region, e.g., Indonesia, Bangladesh, Vietnam, Philippines,

- Comparison of SMM in emerging economies to the evolution and development of SMM in developed economies in the Asian region (Japan, Korea) and beyond (US and Europe).

Given the fast pace of developments in SMM, it might also be useful to revisit the MSE Top 20 companies in a few years to observe how these companies have developed since the last data collection.

Scholarly research into SMM as an international phenomenon is a new and promising area in marketing studies. A focus on SMM, as it evolves within emerging and developing economies, and not just as a tool of global multinational companies to sell to them, is an important part of this promising area of research.

\section{References}

Berthon, P. R., Pitt, L. F., Plangger, K., \& Shapiro, D. (2012). Marketing Meets Web 2.0, Social Media, and Creative Consumers: Implications forInternational Marketing Strategy. Business Horizons, 55(1), 261-271. http://dx.doi.org/10.1016/j.bushor.2012.01.007

Borker, D. R. (2013a). Economic Drivers and Cultural Values: The 3G Countries. The Business Review, Cambridge, 20(2).

Borker, D. R. (2013b). Accounting and Cultural Values: IFRS in the $3 \mathrm{G}$ Economies. International Business \& Economics Research Journal, 12(6).

Buiter, W., \& Rahbari, E. (2011). Global Growth Generators: Moving beyond 'Emerging Markets' and 'BRIC'. Citigroup Global Markets, Citi Investment Research \& Analysis. Chicago: Citigroup Global Markets.

Burgess, S. M., \& Steenkamp, J. B. E. (2006). Marketing Renaissance: How Research in Emerging Markets Advances Marketing Science and Practice. International Journal of Research in Marketing, 23(1), 337-356. http://dx.doi.org/10.1016/j.jiresmar.2006.08.001

Chana, N. L., \& Guilleta, B. D. (2011). Investigation of Social Media Marketing: How Does the Hotel Industry in Hong Kong Perform in Marketing on Social Media Websites? Journal of Travel \& Tourism Marketing, 28(4), 345-368. http://dx.doi.org/10.1080/10548408.2011.571571

Constantinides, E. R. (2008). Social media: a new frontier for retailers? European Retail Research, 22(1), 1-28.

Dawar, N. D., \& Chattopadhyay, A. (2002). Rethinking Marketing Programs for Emerging Markets. Long Range Planning, 35(5), 457-474. http://dx.doi.org/10.1016/S0024-6301(02)00108-5

Dholakia, U. M., \& Talukdar, D. (2004). How Social Influence Affects Consumption Trends in Emerging Markets: An Empirical Investigation of the Consumption Convergence Hypothesis. Psychology \& Marketing, 21(10), 775-797. http://dx.doi.org/10.1002/mar.20029

Finpro. (2012). Current Economic Situation of Mongolia-Brief Introduction. Ulaanbaatar, Mongolia: Fincenter. 
Fisher, T. (2009). ROI in Social Media: A Look at the Arguments. Journal of Database Marketing \& Customer Strategy Management, 16(1), 189-195. http://dx.doi.org/10.1057/dbm.2009.16

Gilfoil, D. M. (2012). Mapping Social Media Tools For Sell vs Buy Activities Into Emerging and Developed Markets. International Journal of Management \& Information Systems, 16(1), 69-82.

Internet World Stats. (2012). Retrieved from Internet World Stats: Usaged and Population Statistics.

Jansen, B. Z. (2009). Twitter Power: Tweets as Electronic Word of Mouth. Journal of the American Society for Information Science and Technology. http://dx.doi.org/10.1002/asi.21149

Jessup, J. E. (1989). A Chronology of Conflict and Resolution, 1945-1985. New York: Greenwood Press.

Jobs, C. (2011). A Comparative Analysis of the Adoption Rates of Social Networking and Micro-blogging Between Industrialized and Developing Nations. Journal of International Business Research, 11(1).

Jobs, C., \& Gilfoil, D. (2011). Hofstede's Cultural Dimensions as an Indicator of Adoption Rates of Social Networking and Micro-blogging between Industrialized and Developing Nations. Academy of Marketing Studies Proceedings, 16. Orlando, FL: Allied Academies International Conference.

Kaplan, A. M., \& Haenlein, M. (2010). Users of the world, unite! The challenges and opportunities of Social Media. Business Horizons, 53(1), 59-68. http://dx.doi.org/10.1016/j.bushor.2009.09.003

Kirchgeorg, M., \& Winn, M. I. (2006). Sustainability Marketing for the Poorest of the Poor. Business Strategy and the Environment, 15(1), 171-184. http://dx.doi.org/10.1002/bse.523

Mongolian Stock Exchange. (2012).

Piskorski, M. (2010). Vision Statement: Mapping the Social Internet. Harvard Business Review, 88(7-8).

Sambhanthan, A., \& Good, A. (2012). Strategic Advantage in Web Tourism Promotion: an Ecommerce Strategy for Developing Countries. International Journal of Information Systems in the Service Sector, 1-21.

Subramani, M. (2003). Knowledge-Sharing and Influence in Online Social Networks via Viral Marketing. Communications of the ACM, 12, 300-307. http://dx.doi.org/10.1145/953460.953514

Thackeray, R., Neiger, B. L., Hanson, C. L., \& James, F. M. (2008). Enhancing Promotional Strategies Within Social Marketing Programs: Use of Web 2.0 Social Media. Health Promotion Practice, 9(1), 338-343. http://dx.doi.org/10.1177/1524839908325335

Tkaczuk, A., Badarch, Z., \& Tureckov, I. (2010). Cultural Dimensions Analysis: Russia, Mongolia, Poland Example. Warsaw: Warsaw University of Life Science.

Transparency International. (2012). Corruption Perceptions Index 2012.

Trusov, M., Bucklin, R. E., \& Pauwels, K. H. (2008). Effects of Word-of-Mouth Versus Traditional Marketing: Findings from an Internet Social Networking Site (pp. 1-48). University of Maryland, Robert H. Smith School of Business Working Paper No. RHS-06-065.

Weber, L. (2009). Marketing to the Social Web: How digital Customer Communities Build Your Business (2nd ed.). Hoboken, NJ: John Wiley and Sons. http://dx.doi.org/10.1002/9781118258125

Witkowski, T. H. (2005). Antiglobal Challenges to Marketing in Developing Countries: Exploring the Ideological Divide. Journal of Public Policy \& Marketing, 24(1), 7-23. http://dx.doi.org/10.1509/jppm.24.1.7.63902

World Bank. (2013). Doing Business in Mongolia 2013. World Bank.

\section{Note}

Note 1. Since the data for this study were collected, APU has created a company Facebook site and has minimal presence.

\section{Copyrights}

Copyright for this article is retained by the author(s), with first publication rights granted to the journal.

This is an open-access article distributed under the terms and conditions of the Creative Commons Attribution license (http://creativecommons.org/licenses/by/3.0/). 